\title{
INHIBITION OF COMPOUND 48/80-MEDIATED HISTAMINE RELEASE FROM ISOLATED RAT MAST CELLS BY OOSPONOL-RELATED COMPOUNDS (4-ACYL-ISOCOUMARINS)
}

\author{
Masayasu KIMURA, Isami WAKI and Masaya KOKUBO \\ Department of Chemical Pharmacology, Faculty of Pharmaceutical Sciences, \\ Toyama Medical and Pharmaceutical University, Sugitani, Toyama 930-0I, Japan
}

Accepted February 28, 1978

\begin{abstract}
Oosponol (4-hydroxymethylketone-8-hydroxyisocoumarin) is a metabolic product isolated from Oospora astringens which originated from house dust in a room of an asthmatic patient. The compound and the structurally related isocoumarins were studied to determine the inhibition of histamine release induced by compound $48 / 80$ from isolated rat peritoneal mast cells. The released histamine was assayed by fluorometry. The compounds tested were not observed to release histamine. Some of 4-acyl-isocoumarins inhibited the histamine release at doses less than $10 \mu \mathrm{M}$, whereas the 3-acyl-and the 4-alkyl-compounds were not effective at doses over $100 \mu \mathrm{M}$. The pretreatment of mast cell with the compound for $15 \mathrm{~min}$ before the application of compound 48:80 was more effective than the simultaneous administration. The mode of inhibitory action of KIT-302, 4-(4'-carboxy-benzoyl)-isocoumarin, was non-competitive antagonism to compound $48 / 80$ on the mast cells.
\end{abstract}

Oosponol (4-hydroxymethylketone-8-hydroxyisocoumarin) is a metabolic product isolated from Oospora astringens in so-called air-borne fungi originating from house dust in a room of an asthmatic patient (1). The compound induced a strong contraction with a tachyphylaxis in guinea pig tracheal muscles $(2,3)$. This contraction aroused our interest in studying oosponol in connection with the development of broncheal asthma.

We attempted to determine which agents would act as inhibitors of the contraction of tracheal muscle induced by oosponol and also those which would inhibit histamine release from mast cells.

The present work was a study of whether oosponol and the structurally related compounds stimulate or inhibit the histamine release. Some of those compounds were found to inhibit the histamine release induced by compound $48 / 80$ from isolated rat peritoneal mast cells.

\section{MATERIALS AND METHODS}

Animals: Male Wistar rats weighing $200-300 \mathrm{~g}$ were sacrificed and mast cells were isolated. The suspendion medium of mast cells was phosphate-buffered salt solution, pH 6.8, of the following composition: $\mathrm{NaCl} 154 \mathrm{mM}, \mathrm{KCl} 2.7 \mathrm{mM}, \mathrm{CaCl}_{2} 0.9 \mathrm{mM}, \mathrm{NaH}_{2} \mathrm{PO}_{4}$ $3 \mathrm{mM}, \mathrm{Na}_{2} \mathrm{HPO}_{4} 3 \mathrm{mM}$, bovine albumin (Fraction $\mathrm{V}$, Armour) $0.1 \%$.

Isolation of mast cells: Each rat was first anaesthetized with diethyl ether and decapitated. Ten $\mathrm{ml}$ of the salt solution was administered through an abdominal incision and 
the abdomen was massaged for $2 \mathrm{~min}$. All the peritoneal fluid from at least two rats was pooled and kept in ice-water. The pooled fuid was centrifuged at $300 \mathrm{~g}$ for $5 \mathrm{~min}$ at $4^{\circ} \mathrm{C}$ and the cell pellet was resuspended in $3 \mathrm{ml}$ of the cold salt solution. The suspension was gently layered over $4.8 \mathrm{ml}$ of tetra-layered solution of gum arabic (Sigma) of the following density; $1.045,1.055,1.065,1.075$. The layered solution was centrifuged in a $15 \mathrm{~mm}$ by $105 \mathrm{~mm}$ siliconized glass tube at $1,500 \mathrm{~g}$ for $20 \mathrm{~min}$ at $4^{\circ} \mathrm{C}$. The solution of density less than 1.065 and the top half of the layer of density 1.075 were discarded and the cell pellet was washed with cold medium to free the gum arabic. The purity of mast cell obtained by this procedure was more than $85 \%$ when examined by the staining method using $0.05 \%$ toluidine blue solution, and about $5 \times 10^{5}$ cells were obtained from a rat.

Release of histamine: The mast cell suspensions $(0.2 \mathrm{ml})$ were preincubated with $0.2 \mathrm{ml}$ of the salt solution with or without a test compound at $37^{\circ} \mathrm{C}$ for $15 \mathrm{~min}$ with agitation. To this preincubated suspension $0.2 \mathrm{ml}$ of histamine releaser was added and incubation at $37^{\circ} \mathrm{C}$ was continued for $15 \mathrm{~min}$. The reaction was then stopped by cooling and each tube was centrifuged at $300 \mathrm{~g}$ for $5 \mathrm{~min}$ at $4^{\circ} \mathrm{C}$. The supernatant was assayed for histamine by fluorometry after condensation with o-phthal-aldehyde according to the method of Shore et al. (4) without further purification (5). The percent of histamine release (HR) was calcuculated as follows: $H R=(R-S) /(T-S) \times 100$, where $R$ is the amount of histamine released, $\mathrm{S}$ is the amount of histamine released spontancously and $\mathrm{T}$ is the total histamine content. Total histamine content was determined using the supernatant of $0.2 \mathrm{ml}$ aliquot of the untreated mast cell suspension boiled for 5 min together with $0.4 \mathrm{ml}$ of $0.1 \mathrm{~N} \mathrm{HCl}$. The total amount ranged between $4-8 \mu \mathrm{g}$.

Estimation of inhibitory activity on histamine release: The inhibitory effects of oosponolrelated compounds on histamine release from isolated rat mast cells were investigated with a given dose $(5 \mu \mathrm{g} / \mathrm{ml})$ of compound $48 / 80$. The percent of inhibition for histamine release was calculated by comparing the percent of histamine release by compound $48 / 80$ in the tubes with a drug (D) and that in the control tubes without a drug (C) as follows: percent of inhibition $=(C-D) / C \times 100$. The doses of test compounds required for $50 \%$ inhibition with its $95 \%$ confidence limits were also calculated.

Compounds used: Compound 48/80 was obtained from Sigma Co., Ltd. and phosphatidyl-L-serine from Nakarai Chemicals, Ltd. (Kyoto, Japan). Oosponol-related compounds used were synthetized in our own laboratory.

\section{RESULTS}

Histamine-relcase inhibiting activity: Oosponol, and deoxy-oosponol glycinate (DOG) which is a water-soluble analogue of oosponol were investigated as to properties which would induce histamine release from rat peritoncal mast cells. Neither compound induced the histamine release in the absence or even in the presence of phosphatidyl-L-serine $(10 \mu \mathrm{g} /$ mi) which enhanced IgE-mediated release of histamine, although compound $48 / 80$ as a positive control induced the histamine release under our experimental conditions.

DOG was found, conversely, to inhibit the histamine release induced by compound 
48/80. Hence, a study was first done on the relation of the preincubation time of DOG to the inhibitory effect on histamine release. As shown in Fig. 1, the percent of inhibition of histamine release induced by DOG was increased by increasing the preincubation time to 15 min. The preadministration of DOG was effective for the inhibitory activity.

Dose-inhibition curves of DOG and sodium salicylate preincubated with mast cells for

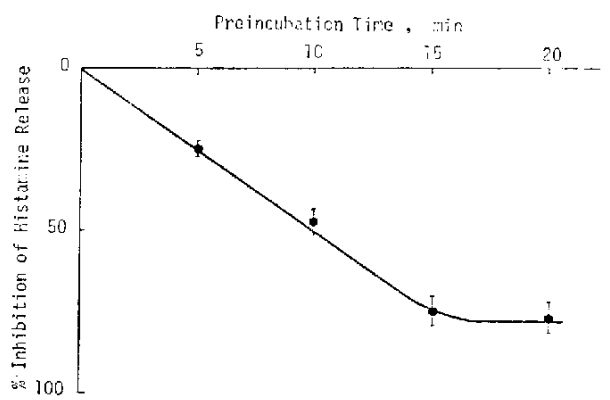

FIG. I. Time course of the inhibitory effect of $5 \mu \mathrm{g} / \mathrm{ml}$ deoxy-oosponol glycinate (DOG) on histamine release induced by compound $48 / 80(5, \mathrm{~g} / \mathrm{ml})$ from isolated rat mast cells. Preincubation with mast cells for 15 min was necessary for the full action.

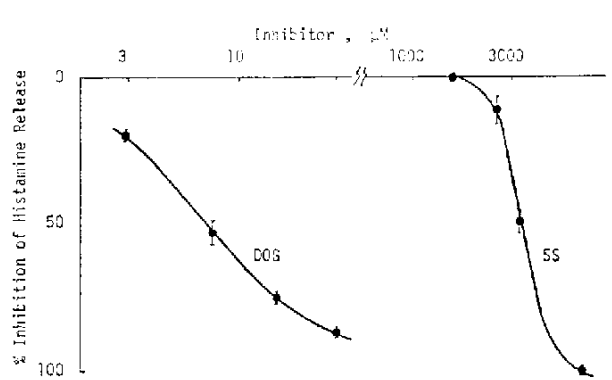

FIG. 2. Dose-response curves of DOG and sodium salicylate (SS) in the inhibition of histamine release induced by compound $48 / 80(5 \mu \mathrm{g} / \mathrm{ml})$ from isolated rat mast cells. DOG was about 400 fold more effective than sodium salicylate.

TABLE 1. Inhibition of histamine relcase from isolated rat mast cells by oosponol and related compounds

Compounds

\begin{tabular}{|c|c|c|c|c|}
\hline & $\mathrm{R}_{3}$ & $\mathbf{R}_{4}$ & $\mathbf{R}_{8}$ & \\
\hline Oosponol & $-\mathrm{H}$ & $-\mathrm{COCH}_{2} \mathrm{OH}$ & $-\mathrm{OH}$ & $3.4(2.8-4.0)$ \\
\hline DOA & $-\mathrm{H}$ & $-\mathrm{COCH}_{2} \mathrm{OCOCH}_{3}$ & $-\mathbf{H}$ & $5.8(4.3-7.9)$ \\
\hline \multirow[t]{3}{*}{ DOG } & $-\mathrm{H}$ & $-\mathrm{COCH}_{2} \mathrm{OCOCH}_{2} \mathrm{NH}_{2}$ & $-\mathbf{H}$ & $7.0(6.3-7.7)$ \\
\hline & $-\mathrm{H}$ & $-\mathrm{COCH}_{2} \mathrm{CH}_{2} \mathrm{~N}\left(\mathrm{CH}_{3}\right)_{2}$ & $-\mathrm{H}$ & $9.2(8.0-10.6)$ \\
\hline & $-\mathrm{H}$ & $-\mathrm{COCH}_{3}$ & $-\mathbf{H}$ & $26(21-32)$ \\
\hline \multirow[t]{3}{*}{ KIT-301 } & $-\mathrm{H}$ & $-\mathrm{CO}-\mathrm{C}_{6} \mathrm{H}_{4}-4^{\prime}-\mathrm{OH}$ & $-\mathbf{H}$ & $620(510-770)$ \\
\hline & $-\mathrm{H}$ & $-\mathrm{CO}-\mathrm{C}_{6} \mathrm{H}_{3}-2^{\prime}-4^{\prime}-\mathrm{diOH}$ & $-\mathbf{H}$ & $>1000$ \\
\hline & $-\mathbf{H}$ & $-\mathrm{CO}-\mathrm{C}_{6} \mathrm{H}_{4}-4^{\prime}-\mathrm{OCH}_{3}$ & $-\mathrm{H}$ & $>1000$ \\
\hline \multirow[t]{3}{*}{ KIT -302} & $-\mathrm{H}$ & $-\mathrm{CO}-\mathrm{C}_{6} \mathrm{H}_{4}-4^{\prime}-\mathrm{COOH}$ & $-\mathrm{H}$ & $8.3(7.4-9.2)$ \\
\hline & $-\mathrm{H}$ & $-\mathrm{CO}-\mathrm{C}_{6} \mathrm{H}_{4}-4^{\prime}-\mathrm{COOC}_{5} \mathrm{H}_{11}$ & $-\mathrm{H}$ & $370(320-430)$ \\
\hline & $-\mathrm{H}$ & $-\mathrm{CH}_{3}$ & $-\mathrm{H}$ & $>1000$ \\
\hline KIT-201 & $-\mathrm{H}$ & $-\mathrm{C}_{6} \mathrm{H}_{4}-4^{\prime}-\mathrm{OH}$ & $-\mathrm{H}$ & $160(140-190)$ \\
\hline \multirow[t]{3}{*}{ KIT-202 } & $-\mathbf{H}$ & $-\mathrm{C}_{6} \mathrm{H}_{4}-4^{\prime}-\mathrm{COOH}$ & $-\mathrm{H}$ & $2800(1700-4200)$ \\
\hline & $-\mathrm{COCH}_{2} \mathrm{OH}$ & $-\mathrm{H}$ & $-\mathbf{H}$ & $260(230-310)$ \\
\hline & $-\mathrm{COCH}_{3}$ & $-\mathrm{H}$ & $-\mathrm{H}$ & $460(340-620)$ \\
\hline
\end{tabular}

$50 \%$ Inhibitory

doses (95\% confidence limits) $\mu \mathrm{M}$

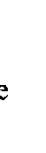




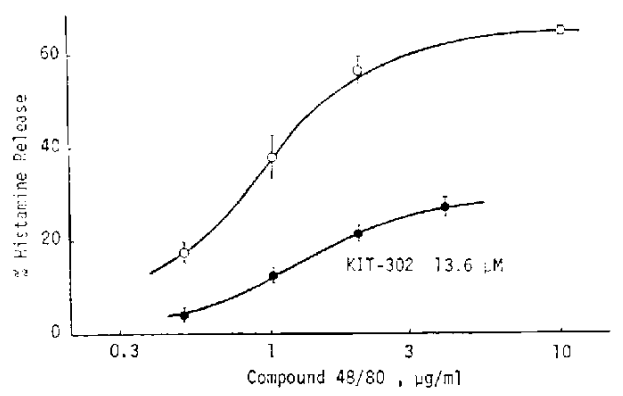

FIG. 3. Dose-response curves of compound $48 / 80$ in histamine release from isolated rat mast cells in the presence (O) and in the absence (O) of KIT-302 $(13.6 \mu \mathrm{M})$. The dose-response curves was inhibited unsurmountably by KIT-302.

$15 \mathrm{~min}$ were plotted in Fig. 2. The inhibitory effects were dose-dependent, and the ID50 of DOG and sodium salicylate was $7.0 \mu \mathrm{M}$ and $3.0 \mathrm{mM}$, respectively.

Structure-activity relationships of inhibition of histamine release: Since an oosponol analogue was found to induce an inhibition of histamine release, the structural requirements for the inhibition were studied by comparing with the oosponol-related compounds. The results of inhibiting activities of compounds tested are summarized in Table 1. It is clear from this table that the acyl groups are required for the optimal inhibitory activity. Also, it has been shown that there are the marked differences in effectiveness between oosponol and 3-hydroxy-acetyl isocoumarin and between 4-acetyl isocoumarin and 3-acetyl isocoumarin, indicating that the 4-acyl substituents are more important for the activity than 3-acyl groups. The compounds which had an alkyl group in the 4-position were not effective. In the 4-acyl group the keton of $\alpha$ position is important for the activity. On the other hand, it is also possible that the hydroxy group in the 8-position of isocoumarin plays an important role. We have found that the potent compound KIT-302 inhibits histamine release induced by compound $48 / 80$ from mast cells.

The mode of antagonistic action of KIT-302 was examined in detail against the histamine release induced by compound $48 / 80$ as shown in Fig. 3. Since the inhibition induced by KIT-302 was not overcome by increasing the dose of compound $48 / 80$, the mode of action appeared to be a non-competitive type.

\section{DISCUSSION}

It has been reported that some isocoumarin derivatives possess activities of smooth muscle contraction (2), purgative $(6,7)$, antimicrobial (8), inhibition of mitochondrial respiration (9) and/or competitive inhibition with gibberellic acid (10). The histamine release inhibition discussed in this paper is different from the activities of the aforementioned isocoumarins. DOG, for example, was about 400 fold more effective an inhibitor of histamine release than was sodium salicylate $(11,12)$.

Selected from a number of compounds synthesized as possible inhibitors of tracheal muscle contraction induced by oosponol, the fifteen compounds listed in Table 1 were 
studied regarding structure and activity relationships. Such was an attempt to determine effective 4-acyl-isocoumarins with both a histamine release inhibiting activity and a tracheal muscle relaxing activity. KIT-302 possessed a potent inhibitory activity of the histamine release and a relatively weak relaxing activity on tracheal muscle. In the case of oosponol, contraction of the tracheal muscle was induced. The effectiveness produced by the preadministration was in contrast to the ineffectiveness in the case of disodium cromoglycate (13). In light of our evidence, 4-acyl-isocoumarin may act as a prophylactic drug in cases of broncheal asthma.

Finally, the mode of inhibitory action of KIT-302 suggested a non-competitive antagonism against compound 48/80. However, if a histamine releaser (except compound 48/80) is used, its action may be competitively inhibited by KIT-302.

Acknowledgements: Gratitude is due to the late Prof. Ohashi of Nippon Medical School, Tokyo for his encouragement and the sample of oosponol. We are also indebted to Miss Y. Ito, and Mr. S. Togashi, for technical assistance.

\section{REFERENCES}

1) Nitta, K., Imai, J., Yamamoto, I. and Yamamoto, Y.: The metabolic products of oospora astringens (Part V). Determination of the chemical structure of oosponol by synthesis: Agr. biol. Chem. 27, 817-821 (1963)

2) Ohashi, S., Yamaguchi, M. and Kobayashi, Y.: Pharmacological studies on anaphylactic and oosponol-induced contraction of tracheal muscle preparation from guinea pigs. Proc. Japan Acad. 38, 766-771 (1962)

3) Yamaguchi, M.: Studies on the metabolic products of air-borne fungi (Report I). In vitro experiment of contraction elicited by metabolic products of air-borne fungi and anaphylactic contraction of tracheal muscle preparation from guinea pigs. Folia pharmacol. japon. 60, 588-599 (1964) (Abs. in English)

4) Shore, P., Burkhalter, A. AND COHN, V.: A method for the fluorometric assay of histamine in tissues. J. Pharmacol. exp. Ther. 127, 182-186 (1959)

5) Bergendorff, A. AND UvNäs, B.: Storage of 5-hydroxytryptamine in rat mast cells. Evidence for anionic binding to carboxyl groups in a granule heparin-protein complex. Acta physiol. scand. 84, 320-331 (1972)

6) Buv Hor, M.: Purgative properties and chemical constitution. Comp. Rend. 210, 418-420 (1940)

7) BarRY, R.D.: Isocoumarins, Developments since 1950. Chem. Rev. 64, 229-260 (1964)

8) Fujikawa, F., Hirayama, T., Nakamura, Y., Slzcki, M., Doi, M. and Niki, C.: Studies on antiseptics for foodstuff, LXXI, Studics on orsellinic acid ester, $\beta$-orcinolcarboxylic acid esters and olivelonide as a preservative for sake. Yakugaku Zasshi 90, 1517-1519 (1970) (in Japanese)

9) Moore, J.H. ANd Truelove, B.: Orhratoxin A.; Inhibition of mitochondrial respiration. Science 168, 1102-1103 (1970)

10) Berrie, A.M.M., Parker, W., Kvights, B.A. and Hendrie, M.R.: Studies on lettuce seed germination. I. Coumarin-induced dormancy. Phytochemistry 7, 567-573 (1968)

11) Yamasaki, H. AND SaEkI, K.: Inhibition of mast cell degranulation by anti-inflammatory agents. Archs int. Pharmacodyn. Thér. 168, 166-179 (1967)

12) Champion, G.D., Day, R.O., Ray, J.E. AND Wade, D.N.: The effect of non-steroidal anti-inflammatory drugs on adenosine triphosphate content and histamine release from rat peritoneal cell suspensions rich in mast cells. Brit. J. Pharmacol. 59, 29-33 (1977)

13) Orr, T.S.C., Hall, D.E., Gwilliam, J.M. and Cox, J.S.G.: The effect of disodium cromoglycate on the release of histamine and degranulation of rat mast cells induced by compound 48/80. Life Sci. 10, 805-812 (1971) 